M. Bakir

\title{
MENELUSURI SEKULARISME DALAM KONTEKS KEBERAGAMAAN
}

\author{
Universitas Nurul Jadid Paiton Probolinggo \\ Email: bakir.muzanni@gmail.com
}

\begin{abstract}
Abstrak: Gerakan sekularisme seringkali dianggap sebagai bentuk kemodernan bagi suatu komunitas tertentu, yang ditandai dengan rasionalitas sebagai identitasnya. Pun demikian, tidak dapat dipungkiri keberadaan gerakan sekularisme telah mempengarubi konsep dan perilaku keagamaan masyarakat. Karena modernisme yang menjadi bungkus sekularisme telah menjelma menjadi sytle, metode, maupun elespresi-elespresi lainnya bagi masyarakat. Sekularisme yang labir di Barat seakan memberi informasi kepada bangsa Timur yang notabene dianggap sebagai masyarakat tertinggal dan berlumur kemiskinan, bahwa jika ingin maju dan terdidik, maka kunci utamanya adalah menjadi masyarakat modern.
\end{abstract}

Kata Kunci: Sekularisme, Keagamaan, dan Masyarakat. 


\section{Pendahuluan}

Imperium Romawi yang menguasai seluruh tatanan kehidupan Barat serta merta memberikan pengaruh pada keagamaan Dunia Timur. Abad ke-16 dan ke-17, adalah permulaan dari bergoncangnya nilai-nillai teokrasi Islam Timur. Dimana, Barat Modern dan seluruh aspeknya yang dikuasai oleh pertimbangan pragmatisme materialis dan ekspansi dinamis, memprakarsai eksperimen modernnya tanpa didasarkan pada landasan keagamaan yang hakiki. ${ }^{1}$

Modernitas pada abad kosmologi tersebut, dinyanyikan oleh Barat dengan wajah sekular dan pada gilirannya mempengaruhi negeri-negeri Timur yang mayoritas Islam dan berlumur kemiskinan. Modernisme merangkap konsep-konsep sekularisasi itu kemudian muncul sebagai sebuah perubahan metode, gaya, prosedur dan bentuk-bentuk ekspresi dalam eksistensi manusia.

Bangsa Timur mulai kehilangan keseimbangan. Islampun menjadi terkungkung dalam pseudo imaginare itu. Apa yang pernah dilontarkan Haedar Nashir bahwa mereka (sebagai manusia Dunia Ketiga) tentang penggugatan pada negara-negara maju di Barat "Anda bidup makmur, terdidik dan modern. Tapi kenapa anda saling membunub?". Seakan sesuka hati, orang-orang Barat menjawab, "Kami membunub karena kami makmur, kami membunub karena kami terdidik, kami juga membunuh karena kami modern".2

Statement Nashir adalah ungkapan kepahitan sebagai ironi kemanusiaan antara dua dunia yang berbeda (hibrida). Disatu sisi, Dunia Ketiga yang memegang tradisi keagamaan yang kental dan Dunia Barat yang melanggengkan rasionalisasi dan desakralisasi eksperimental—sebagai bagian dari sekularisme. Dalam konteks ini,

\footnotetext{
${ }^{1}$ Dihadapkan pada paradoksa modern, manusia sejak abad ke-7 hingga 15, berada dalam posisi benar atau salah, mengatasnamakan Allah, wahyu dan syari'at. Sedangkan sejak abad itulah (16-17), bersama dengan Eropa, mereka dihadapkan pada peradaban baru yang bersumber dari ilham akal (rasionalitas), aktifitas pemerintahan dengan undang-undang lokal_-yang menurut Dr. Hasan Sho'ub—sebuah peradaban yang berangkat atasnama manusia. Lih. Dr. Hasan Sho'ub, Islam dan Revolusi Pemikiran, Dialog Kreatif Ketuhanan dan Kemanusiaan, terj. Mohammad Luqman Hakiem, (Surabaya: Risalah Gusti, 1997), hal. 5. Namun, perlu dicatat bahwa teokrasi Islam Timur juga dipengaruhi oleh sikap peradaban Barat dan upaya pembebasan kehidupan dunia yang luar biasa. Lih. Muhammad Assad, Umat Islam di Simpang Jalan, terj. Muhammad Mahrus, (Jakarta: Fikahati Aneska, 1992), hal. 39.

${ }^{2}$ Lih. Haedar Nashir, Agama dan Krisis Kemanusiaan Modern, (Yogyakarta: Pustaka Pelajar, cet. I 1997), hal. 31
} 
Islam secara terbuka menerima perubahan revolusioner itu sebagai suatu "kemestian".

\section{Memahami Sekularisme: Kontekstualitas}

Pemahaman tentang diskursus sekularisme telah memberikan perhatian pada sejumlah pemikir Islam kontemporer, semacam Mohammed Arkoun. Dalam suatu tinjauannya, Arkoun menyebut bahwa sekularisme diidentikkan sebagai paham yang menghancurkan kapasitas penerimaan dan bimbingan ilahi, atau lebih kepada program kultural dan politis emansipasi dari pemikiran teologis dan dominasi elektiastik, sebagai pengejawantahan dominasi alam untuk meningkatkan kekuasaan manusia dalam substitusi sistem pendidikan publik untuk sistem pendidikan pribadi. ${ }^{3}$ Di Prancis, istilah sekularisme lebih dikenal dengan sebutan laicite atau laicisme, yaitu ekspresi dari sikap militan yang melawan visi religius dunia. ${ }^{4}$ Ini menegaskan konsepsi paham tersebut menekankan nilai-nilai konservatifitas manusia dan agama: bahwa agama tak lebih sekedar warisan transendental yang tidak statis, sehingga diperlukan sikap progresif-aktif untuk menerjemahkannya kembali dalam setiap kehidupan manusia. Namun, sikap ini pula menggarisbawahi praktik-praktik liberalisme dalam percaturan konsepnya yang akhirnya berujung pada upaya "menghilangkan" (negation) identitas agama-agama.

Alasan yang paling mendasari pernyataan tersebut pada tataran historis sosiologis dapat dilihat dari dua pemahaman kunci. Pertama, munculnya istilah sekularisme yang diproduksi oleh pemikir Barat dengan melegitimasi pemberontakan terhadap absolutisme gereja dan sistem kependetaan. ${ }^{5}$ Ini lebih banyak dimotori oleh kalangan yang mengaku atheis dan agnostik dengan merekayasa pemahaman religiusitas kaum beragama. Kedua, Barat yang-juga-lebih banyak beragama Katolik (Kristen) mengukuhkan sekularisasi sebagai sumbangan pemikiran bebas. Legitimasi ini dimunculkan pertama kali oleh John Locke dengan teori kebebasan berfikir (liberalisme)

\footnotetext{
${ }^{3}$ Lih. Mohammed Arkoun, Islam Kontemporer Menuju Dialog antar Agama, terj. Ruslani, (Yogyakarta: Pustaka Pelajar, 2001), hal. 49

${ }^{4}$ Ibid, bandingkan dengan buku Guy Gautier, La Laicite en Mirror, (Paris: Grasset, 1985).

${ }^{5}$ Lih. Drs. A Charis Zubair, Etika Rekayasa Menurut Konsep Islam, (Yogyakarta: Pustaka Pelajar, 1997), hal 110-114
} 
dan atau empirisme dualis-nya. ${ }^{6}$ Sehingga, sekularisme selalu mengidentikkan akan proses desakralisasi terhadap pelbagai teksteks suci (sacred text).

Selain Locke, juga Aguste Comte, filsuf kenamaan yang menganut dasar prositivisme. ${ }^{7}$ Ia memberikan penawaran tentang teori sekularisme sebagai hukum kebudayaan baru yang modern dan dilandasi dengan alam pikiran rasional atau positif. Pernyataan ini kemudian memunculkan kritik rasionalitas terhadap ilmu pengetahuan dan riset ilmiah seperti halnya, kritik ideologi fisikawan Stefen Hawking. ${ }^{8}$ Konsep rasionalitas tersebut dalam konteks sekularisme mengukuhkan teologi kritis yang berusaha melepas prinsip moral alamiah dan agama wahyu (supernaturalisme). Menggaris bawahi pernyataan ini, George Jacob Holyoake, melihat pemahaman ini pada hakikatnya menunjuk pada usaha untuk menikmati peradaban (eksperimentasi-eksperimentasi alam oleh manusia) seolah-oleh tanpa campur tangan Tuhan dan cenderung melakukan interpretasi yang bersifat sekular (sesuai dengan rasionya). ${ }^{9}$

Padahal, hal ini jelas memberikan resistensi yang cukup kuat pada umat beragama dalam menanggalkan identitas keagamaannya yang semula. Karena, ideologi sekularisme yang pada gilirannya memunculkan agama-agama baru seperti fasisme dan maoisme ${ }^{10}$, selalu merujuk pada nuansa kebebasan bertindak dan berfikir (free will and act) pada teks dan konteks manusia serta lingkungannya.

\footnotetext{
${ }^{6}$ Salah satu ajaran liberal Locke adalah bahwa tidak ada asas-asas moral yang merupakan bawaan, sehingga tak satupun pada umumnya dimengerti. Selengkapnya mengenai genealogi dan biografinya lih. Ali Modhofir, Kamus Filsafat Barat, (Yogyakarta: Pustaka Pelajar, 2001), hal. 320-321

${ }^{7}$ Fase filsafat positivistiknya ialah pertama, statika sosial: masyarakat sebagai kenyataan dengan kaidah-kaidah yang menyusun tatanan sosial. Kedua, dinamika sosial: perkembangan masyarakat dalam sejarah dan kemajuannya. Lih. ibid, hal. 103-104

${ }^{8}$ Hawking - yang ketika itu mengalami kelumpuhan dan nyaris kehilangan harapan hidup - mengkritik ideologi ilmu yang dianut manusia modern lebih sempurna dari pada alam pikiran yang bertumpu pada agama dan nenek moyang. Pernyataan ini dikutip dari Kitty Furgosan, Stephen Hawking: Pencarian Teori Segala Hal, terj. (Jakarta: Grafiti, 1995), hal. 5 atau kutipan Haedar Nashir, Op. Cit., hal. 34

${ }^{9}$ Lih. A. Charis Zubair, Op. Cit., hal. 114

${ }^{10}$ Fasisme merupakan dimensi filsafat sosial di Italia yang menolak demokrasi dan kebebasan, serta mendewakan negara sebagai wewenang otoritatif. Gerakan ini dipengaruhi oleh golongan sosial politik yang anti-marxis. Sedangkan maoisme, adalah kelompok aliran Mao Tse-Tung (Ketua Partai Komunis Cina: 1943-1976). Umumnya, doktrinisasi Barat tak berhenti hanya pada tataran realitas keagamaan saja, tetapi juga terhadap teks-teks suci (baca; wahyu transendental). Lih. Mohammed Arkoun, Op. Cit., hal. 50
} 
Konsep kebebasan dalam pola pemikiran sekularisme semacam ini adalah deskripsi dari pemaknaan paradoksal terhadap eksistensi agama yang telah masuk dalam ruang lingkup kehidupan manusia. Pada tataran inilah, sekularisme-sebagaimana Hassan Hanafi menyebut-kemudian menduduki dimensi transisi yang "pertama", suatu pemaknaan terhadap kemajuan (taqaddum); realisasi masa depan di masa kini. Referensi ontologis sebagai analisis interpretatif terhadap terminologi itu-"kemajuan"-bagi Hanafi berasal dari kata "taqaddum" yang diambil dari kata "qadima" yang artinya "ata" " (tiba). ${ }^{11}$ Padahal dalam koridor keislaman, segala tindakan yang tersangkut dengan "nilai" (kodrat manusia dengan lingkungannya), mesti berpegang teguh (i'timad) pada landasan hukum "almuhafadhah "ala al-qadim al-shalih wa al-akhdqu bi al-jadidi al-ashlab" (mempertahankan tradisi lama yang masih relevan, dan responsif terhadap gagasan baru yang lebih baik dan relevan)

Sehingga, pemaknaan terhadap sekularisme setidaknya terhenti pada suatu kesimpulan bahwa istilah tersebut selalu merujuk pada padangan berpikir dan kecenderungan untuk menggunakan materimateri alamiah dengan melepaskan keyakinan terhadap Tuhan. Namun, bukan berarti paham atheis, karena sekularisasi masih menggunakan kontekstualitas religius sebagai dasar pemberontakannya.

\section{Sekularisme : Manifesto Ideologis dan Institusional}

Reaksi para agamawan, pada batas tertentu membantah sikapsikap apatis kaum sekularis. Dengan kebebasan dan pengusungan desakralisasi atas nama modernitas, sekularisme menuntut agamaagama untuk tunduk pada perubahan gaya, pola pikir dan sikap dalam kehidupan. Seperti payung suci, agama-agama justru menjadi peneduh pada krisis kemanusiaan yang dilanda pada abad pencerahan (Enlightment Age) itu. Dengan penekanan revivalisme religius, sekularisme mewujud dengan penyamaran wacana, ritus-

\footnotetext{
${ }^{11}$ Kemajuan (taqaddum) yang dimaksud merupakan kesamaan arti dari 1. ata' (tiba) 2. baliya (usang) 3. taqaddimu (mendatangkan) 4. taqaddama (maju kedepan). Secara derivatif, terminologi tersebut merujuk pada tiga dimensi waktu: masa depan yang datang ke masa kini, masa kini menuju ke masa lalu. Fase pertama dipegang oleh sekularisme. Dan golongan konservatif mengambil langkah ke tiga. Sedangkan Islam Progresif (Kiri Islam) menjadikan tiga-tiganya sebagai landasan teologisnya. Selengkapanya lih. Hassan Hanafi, Oposisi Pasca Tradisi, terj. Khairon Nahdiyyin, (Yogyakarta: Syarikat Indonesia, 2003), hal. 104-105
} 
ritus dan perilaku-perilaku kolektif keagamaan an-sich. Sehingga, sekularisme bergerak bebas, tanpa landasan intelektual etis-sosial dan moral manusia.

Di negara-negara yang notabene jumlah kaum muslim minoritas, seperti India, Sri Langka dan Philipina, Islam memainkan sikap dan peranan yang berbeda. Karenanya, agama Islam juga dipaksa untuk mempertahankan identitasnya tanpa mempunyai komitmen kuat terhadap sistem teokrasi. Hingga, pada akhirnya negara-negara Islam semacam ini terbagi menjadi tiga bagian yang tidak sepenuhnya pro status quo (pemerintahan yang mempunyai aturan kuat terhadap sekularisme) dan cenderung mempertahankan identitasnya pribadi. Pertama, mereka yang menutup modernisasi Barat dan menganggap gejala tersebut sebagai bahaya mutlak. Kedua, mereka yang membuka diri terhadapnya dan menganggap sebagai satu-satunya kunci kemajuan. Dan ketiga, mereka yang selektif terhadap gerakan perubahan itu. ${ }^{12}$

Pengaruh sekularisme yang sedemikian kuat tersebut, cenderung mengganggu kekuatan agama secara berlebihan. Karena, suatu agama yang tumbuh diantara mayoritas agama-agama sekular Barat, akan berusaha memelihara identitas agamanya sendiri. Hal ini dilatari dari sikap penolakan terhadap sistem negara secara personal dan tidak mampu menerima perubahan secara mendadak.

Perangkat-perangkat sekularisme juga semakin berkembang ketika Dunia Barat, mulai mengadakan perluasan (ekspansion) daerah melalui ideologi atau agamanya (gospel). Bangsa-bangsa yang dikenal sebagai agama negara muslim di Asia dan Afrika mulai dipengaruhi oleh pola pikir ajaran baru tersebut. Bahkan, Turki sebagai salah satu negara muslim terbesar konon pernah membangun proyek raksasa sekularisme yang paling naif, sebelum pada akhirnya gagal total. $^{13}$

Saat itu adalah periode mengakarnya sekularisme diseluruh negeri, tak terkecuali Indonesia. Karena, negeri ini dianggap sebagai kampiun nilai-nilai keislaman plural yang masih baru jejak-jejak historis dan pemahaman agama. Munculnya aliran ini membuat perseteruan sengit diantara watak pemikiran Islam tradisional

\footnotetext{
${ }^{12}$ Lih. K.H. Ali Yafie, Menggagas Fiqih Sosial, (Bandung: Syarikat Indonesia, 2003), hal. 104-105

${ }^{13}$ Lih. Asghar Ali Enginer, Islam dan Teologi Pembebasan, terj. Agung Prihantoro, (Yogyakarta: Pustaka Pelajar,cet. III 2003), hal. 233-234
} 
Indonesia dan corak doktrin keberagamaan dunia sekular yang sama sekali bebas.

Noercholish Madjid, intelektual Islam Indonesia pada awal tahun 1970-an adalah salah seorang yang nyaris mendukung bentuk dan polarisasi sekularisme. Cak Nur (demikian sapaan akrabnya) melemparkan isu tentang perlunya proses desakralisasi ilmu dan dunia, sebagai inti dari seruan sekularisasinya. Meski, dalam konteks Sayyed Hossein Nasr dan Fritjof Schoun, beliau masih belum mencapai titik ultimate sekularisme sebagai promethean man (sebuah simbol pemikir bebas dan tokoh kemerdekaan Yunani). ${ }^{14}$

Kebangkitan doktrinisasi sekularisme juga lebih berkembang ketika pada rentang tahun 1970-1980-an, Italia yang 30 dekade sebelumnya merupakan masyarakat Katolik yang besar mengalami sekularisasi yang luar biasa. Dimana, masyarakat Katolik teridentifikasi hanya $30 \%$ dari seluruh angka tertinggi di Eropa. Agama di Italia memang tidak hilang, tapi penduduknya hampir seluruhnya tersekularkan. ${ }^{15}$ Agaknya, pernyataan ini adalah awal terjangkitnya split personality ${ }^{16}$ orang Eropa Barat akibat sekularisasi yang memberikan legitimasi sisi negatif agama.

Sehingga, apa yang pernah disebut sebagai "institutional secularazation" (sekularisasi kelembagaan) akhirnya benar-benar terjadi di Eropa yang bermula dari stagnan konstitusi demokrasi modern yang liberal. Selain juga dihantui dengan nilai-nilai dan produk-produk kapitalisme di bidang agama, negasi normatif terhadap agama pada saat yang sama telah mengakar secara teoritis. Sebagai akibat dari gagasan-gagasan European Enlightment tersebut, dinamika sekularisasi memunculkan para atheis dan agnostis yang tidak sedikit jumlahnya.

\footnotetext{
${ }^{14}$ Menurut Nasr, manusia promethean adalah suatu penemuan yang beru muncul pada masa akhir abad pertengahan, ketika terjadi "eksteriorisasi” ajaran Kristen karena pengaruh averroisme - versi filsafat Ibn Rusyd Eropa Barat. Pernyataan ini dapat dilihat di Prof. Dr. M. Dawam Rahardjo, Ensiklopedi Al-Qur'an, Tafsir Sosial Berdasarkan KonsepKonsep Kunci, (Jakarta: Paramadina, 2002), hal. 56. selengkapnya dalam buku Sayyed Husein Nasr, Knowledge and The Secred, (New York: State University of New York, 1989)

${ }^{15}$ Lih. Karl-Josef Kuschel et.al, Agama Sebagai Sumber Kekerasan?, terj. Imam Baehaqie, (Yogyakarta: Pustaka Pelajar, 2003), hal. 135-136

${ }^{16}$ Split personality diartikan dengan "kepribadian yang terpecah" yang dipengaruhi tindakan-tindakan sadisme antar publik dan privat semisal pembunuhan pada famili dan dikotomisasi publik tanpa pembatasan teologis kemanusiaan. Lih. Hamdi Muluk, "Split Personality” atau "Schizophrenia” Sosial? Dalam Kompas, Sabtu, 12 Mei 2001
} 
Lain halnya di Eropa, Amerika merupakan negara yang mengakui keberadaan agama dan negara dalam struktur masyarakat modern. Pemusnahan agama di atas panggung negarasebagaimana dijustifikasi di Eropa-tidak diakui di Amerika. Tipologi kontradiktif dari kedua wilayah ini bisa ditunjukkan dengan perspektif para intelektualnya. Misalnya, dalam perdebatan teori seorang intelektual Amerika, Mark Twain yang beragama atheis dan George Bernard Shaw, intelektual Eropa yang sekular tentang Saint Joant (seorang santo Kristen yang menguasai bahasa arab dan menggali ilmu-ilmu keagamaan) ketika itu. Atau Franklin Littel yang mensinyalir eksistensi kelompok pembesar Gereja di kedua negara tersebut. $^{17}$

Dalam tradisi keberagamaan Barat (baik Amerika ataupun Eropa), mengakui bahwa akar utama bangkitnya sekularisasi pada hakikatnya berawal dari proses desakralisasi dan rasionalisasi. Dengan proses demikian, manusia (beragama) diseret pada wilayahwilayah personal semata (eksplorasi rasionalistik), tanpa landasan etika sosial dan teks-teks religius. Ilham untuk melakukan interpretasi ulang terhadap teks-teks tersebut, merujuk pada kematangan pola pikir manusia di alam modernitas. Sehingga, banyak universitas-universitas sekular yang dibangun untuk kalangan-kalangan konservatif terhadap agama.

Bahkan, dalam sisi politik-institusional, Asghar Ali Engineer merepresentasikan bentuk-bentuk sekularisme yang berwujud dalam Jami'at al-Ulama atau Jama'at-e-Islami di India. ${ }^{18}$ Teolog Islam yang berkumpul dalam institusi itu, berpartisipasi dalam sistem politik sekular dan mendukung adanya perubahan dalam bidang sosioekonomi. Kehadiran sistem sekularisme, memberikan dogma baru terhadap nilai-nilai kemanusiaan di negara tersebut. Tidak ada pertentangan atau fatwa perlawanan pada tindakan-tindakan di luar batas kesadaran ketika itu, seperti nasionalisasi bank atau eksploitasi terhadap buruh.

\footnotetext{
${ }^{17}$ Menurutnya Gereja di Eropa kesulitan membendung lahirnya kelompok anti Gereja, sedangkan di Amerika Gereja masih mendapat kesempatan untuk berpartisipasi dalam percaturan kehidupan masyarakat. Lih. analisa historis sosiologis Alwi Shihab, Membedah Islam di Barat, Menepis Tudingan Meluruskan Kesalahpahaman, (Jakarta: PT. Gramedia Pustaka Utama, 2004), hal. 25-28

${ }^{18}$ Lih, Asghar Ali Enginer, Op. Cit., hal. 234
} 
Konfigurasi pengaruh sekularisme ini menuntutnya untuk memilih menjadi negara sekular-demokratis. Seperti Indonesia, India yang lebih dikenal sebagai negara plural, tidak dapat menegakkan demokrasi tanpa sekularisme dalam konteks modernitas dan sekularisme juga tidak dapat menciptakan stabilitas tanpa pemahaman terhadap pluralisme. ${ }^{19}$

Dari deskripsi inilah, dapat diambil pemahaman bahwa sekularisme tidak hanya memberikan pengaruh terhadap ketentuanketentuan suci agama, tetapi juga ada golongan yang menaruh sekularisme dalam proporsi yang plural. Dimana, sekularisme diwujudkan sebagai bentuk pemahaman tentang toleransi dan pluralisme antar agama yang berbeda. Dalam konteks ini pula, sekularisme masih digunakan untuk mempertahankan sistem-sistem demokratis yang telah terbangun. Namun, setelah semuanya terhenti, ketika sekularisme berdiri tegak ditengah-tengah struktur kelembagaan dan ideologisya, pemaknaan terhadap agama-agama juga semakin meningkat. Proyek pembangunan perangkatperangkat sekularisme dalam konteks kehidupan beragama, kini berpindah mendekati pemahaman-pemahaman yang lebih kontekstual dengan dukungan para pemikir-pemikir post modern yang memberikan pijakan konseptual dalam memahami lebih jauh tentang sekularisme.

\section{Penggugatan Sekularisme: Suatu Pemaknaan}

Dalam perjalanannya, sekularisme memunculkan polemik yang cukup menarik. Terutama dalam tradisi Islam Timur yang masih memegang kokoh pemaknaan tradisional religius. Islam mempunyai pandangan sendiri dalam mengeksplorasi teks-teks Al-Qur'an dan Al-Hadits, namun sekularisme memunculkan rasionalitas sebagai dasar interpretatif. Kedua tipe ideologi ini (baca; keyakinan) terkesan bertumpang tindih antara satu dan yang lain.

Demikianlah, Ernest Gellner serta merta menegaskan "Islam masib kuat sampai sekarang, sekuat satu abad yang lalu. Dalam beberapa hal barangkali jauh lebih kuat". Hingga sampai pada semangat optimisme "sejauh ini ada indikasi bahwa Islam akan mengalabkan

\footnotetext{
${ }^{19}$ Ibid, hal. 306
} 
sekularisasi di masa depan". ${ }^{20}$ Statement tersebut adalah ungkapan jujur dari seorang Gellner yang lebih memilih menguatkan sistemsistem Islam dalam konteks sekularisme. Pernyataan Gellner dilatari dari kebimbangan yang pasang surut tentang posisi Islam yang hampir luntur dalam menghadapi efek kejut modernisme. Memang, kekuatan Islam dapat diyakini karena teks-teks suci (Al-Qur'an dan Al-Hadits) adalah susunan teks yang sakral dan tidak boleh digugat. Serta eksperimentasi-eksperimentasi alamiah manusia pada hakikatnya berasal dari teks-teks tersebut.

Lebih jauh, Islam sendiri secara tak langsung "menggugat" paham-paham sekularisme yang menunjuk pada pergolakan nilainilai spiritual dan sosial. Manusia sekular menjadi serba pragmatis dan hedonis karena selalu mempertimbangkan nilai-nilai kegunaan dan keduniawian semata. Corak sikap dan karakteristik semacam ini yang sering disebut dalam Islam sebagai serakah, melampaui batas (ishraf) dan dipertentangakan dalam Al-Qur'an. Allah memberikan instrumen "Ketahuilah, sesunggubnya manusia itu benar-benar melampaui batas, karena merasa serba cukup" (Al-“Alaq : 6-7). ${ }^{21}$ Pembatasan yang ditawarkan Al-Qur'an tersebut pada gilirannya memagari watak manusia yang serakah, sehingga sekularisme tidak mudah melakukan pembunuhan budaya melalui perangkat-perangkat rasionalistik dan mekanisnya.

Seperti yang ditulis oleh Prof. Dr. Ahmad Syafi'i Ma'arif dalam Gatra, No 23/Th. III/1997, bahwa sekularisme yang menjadi basis pemikiran dan budaya modern tidak mungkin berjaya pada sebuah bangsa muslim selama belajar dari kasus Turki, meski dipaksa secara politis dan militer. Karena terbangun di atas penolakan terhadap nilai-nilai spiritual, sekularisme akan luluh dengan komitmen keislaman yang dibangun secara kolektif. Evaluasi yang dilakukan Ma'arif tersebut adalah pengalaman belajar dari Islam (kaum beragama pada umumnya) yang selama masa modern terusik dengan pemahaman yang rendah tentang agama dan teks-teks suci sebagai pedoman kehidupan.

Tidak hanya itu, pemahaman itu juga sempat dinyatakan oleh Hans Kung sebagai pengajar teologi Katolik yang sebelum pada

\footnotetext{
${ }^{20}$ Lih. Dr. Alwi Shihab, Islam Inklusif, Menuju Sikap Terbuka dalam Beragama, (Bandung: Mizan, cet I 1997), hal. 111. selengkapnya pernyataan Gellner tersebut di bukunya "Flux and Reflux in The Faith of Man" dalam Muslim Society, 1992, hal. 1-85

${ }^{21}$ Lihat pula ayat-ayat lain dalam At-Takatsur: 1-2 dan Al-'Araf: 31
} 
akhirnya dicabut oleh missio canorica (hak resmi dari Vatikan) pada tanggal 18 Desember 1979, karena ajarannya yang tidak sesuai dengan semangat ajaran Katolik. Kung melukiskan pengembaraan intelektualnya ketika bersama dengan dua Era yang berbeda; Era Modern ke Post Modern, yang merupakan periode transisi dalam konteks agama-agama. Lewat bukunya Theology for The Third Millenium, Kung melihat bahwa usaha meniadakan agama seperti yang dilakukan oleh orang-orang sekularis dan para filsuf ateistik semacam Marx dan Nietazche menemukan jalan buntu. Kebebasan yang di"pertuhakan"kan oleh orang-orang modern justru mengancam proses pembudakan manusia modern sampai titik nol. ${ }^{22}$ Kemutlakan personal yang dialami oleh manusia modern waktu itu pada akhirnya akan mewujud sebagai krisis spiritual (spiritual crisis).

Terlepas dari itu, pada sisi lain sekularisme yang menganjurkan generalisasi agama menolak tindakan statis, kaku (frozen) pada teksteks suci. Teologi ini mengajarkan bahwa teks "sepenuhnya" dipasrahkan pada akal (rasionalitas) agar ditemukan kompleksitas pemahaman yang komprehensif. Padahal, Islam mempunyai metode sendiri dalam menginterpretasi (tafsir) atau menganalogikan (qiyas) teks-teks Al-Qur'an secara kolektif.

Cara berfikir semacam ini, menggejala hampir pada semua pemaknaan-pemaknaan realitas sekularisme yang kemudian banyak dibantah oleh pemikir-pemikir post-modern. Bahkan, kenyataan kritik rasionalitas yang dilakukan oleh kaum sekularis sebagaimana pembuktian empirisme rumusan fisika atom oleh Einstein dan astrofik oleh Hawking bukanlah suatu kenyataan ilmiah yang cenderung ditafsirkan miring dengan istilah supra-natural. Namun, Allah SWT sendiri mengasosiasikannya dengan istilah terminologi fawq al-thabi'ah atau ma wara' al-maddah yang merupakan kesamaan arti dengan kata metafisika (khariq al-'adah). Dimana, hukum-hukum yang terjadi dalam kosmos ini hanyalah "hukum kebiasaan" (sunnatullah) yang telah ditetapkan Allah untuk ciptaan-Nya. ${ }^{23}$

\footnotetext{
${ }^{22}$ Lih. St. Sunardi, Dialog: Cara Baru Beragama, Sumbangan Hans Kung bagi Dialog Antar Agama dalam Dialog: Kritik dan Identitas Agama, (Yogyakarta: Pustaka Pelajar, 1993), hal. 55-72

${ }^{23}$ Lih. Sachiko Murata, The Tao of Islam, terj. Rahmani Astuti dan M.S. Nasrullah, (Bandung: Mizan, 1996), hal. 165-191. terutama yang berkaitan dengan kosmologi
} 
Hanya saja, kelemahan dalam menguatkan pergolakan teks atas realitas dalam struktur makro, ialah agama Islam tak mampu menetralisir aspek historis-sosiologis sebagai kekuatan integral yang profetik bagi aktualisasi nilai-nilai religiusitasnya. Dibutuhkannya komodifikasi komprehensif ditujukan untuk mempertahankan teks yang genuine diatas paradigma "keserakahan dehumanisasi" yang dipraktikkan kaum-kaum sekular. Struktur makro-kosmos yang begitu kompleks dan dimensional mesti ditopang dengan pengakuan atas pemahaman keagamaan. Hingga, pada gilirannya afiliasi dari dua sub sistem_antara "teks" dan "realitas"_akan mewujud kekuatan sublimasi (pembersih) dan liberasi (pembebas) yang menggusur arus meodernisasi yang pragmatik, materialistik dan sekular itu.

Perangkat-perangkat tersebut merupakan acuan "jati diri” sekularisme yang dipahami sebagai reaksi fatal terhadap keterasingan manusia (beragama) dengan eksistensi yang Absolut, Tuhan. Terbentuknya peradaban manusia dan aktifitas naluriah di"erosi"kan dari pemaknaan terhadap kuasa takdir (predestination). Sehingga, legitimasi teologis yang menyatukan akar-akar teks pada fenomena-fenomena alam dengan pemahaman final akan sunnatullah, semakin menggugurkan paradigma-paradigma sekularistik.

Penafsiran teks dan otoritas transendental, dalam hal ini, hampir tidak berbeda dengan asumsi Richard E. Palmer yang menemukan corak hermeneutika yang lebih elusif dan historis. Karena, salah satu rujukan struktur hermeneutika berupa "karya" (kumpulan teks-teks) yang selalu dibuat dengan sentuhan tangan manusia (atau Tuhan). Sehingga, berkembang sebagai usaha pemahaman yang lebih spesifik pada model-model pemahaman historis dan humanistik. ${ }^{24}$ Lain halnya dengan ajaran para sekularis yang justru meninggalkan pemaknaan sintagmatik dengan penulusuran yang lebih mendalam antara keduanya. Hingga, terlihat adanya kelemahan (kegagalan) preferensi kehadiran nalar pada AlQur'an secara orisinil. Kapasitas metode berfikir yang dilakukan oleh kaum sekularis melepas acuan-acuan normatif terhadap landasan hermeneutik itu dalam proses desakralisasi dan atau interpretasinya.

\footnotetext{
${ }^{24}$ Lih. Richard E. Palmer, Hermeneutika: Teori Baru Mengenai Interpretasi, terj. Mansur Hery dan D. Muhammed, (Yogyakarta: Pustaka Pelajar, 2003), hal. 7-8
} 


\section{Kesimpulan}

Munculnya gerakan-gerakan sekularisme harus diakui sebagai pentahbisan modernisasi di dunia Eropa. Dimana, modernisasisebagaimana analisis Daniel Bell-meniscayakan rasionalitas sebagai identitas dan idealitas manusia modern. ${ }^{25}$ Pada titik ini, kulminasi akar-akar doktrin sekularisme bergerak melepaskan keterikatan teksteks diatas pondasi teologis (naql) dan menuju apa yang disebut Arkoun sebagai nalar ('aql). Namun, setelah fase berlangsungnya teori-teori peradaban Eropa mencapai poros final, kreatifitas berhenti, Eropa telah menyelesaikan periodenya dan berakhirlah sejarah. ${ }^{26}$ Begitu juga sekularisme yang pada akhirnya digugat dengan pendekatan-pendekatan semiotik teologis sebagai bagian yang tidak dapat diterima dalam struktur nilai-nilai kemanusiaan. Perseteruan tersebut, alangkah baiknya kita sikapi secara arif dan bijak, memahaminya sebagai kebebasan berfikir secara plural dan obyektif. Kita - sebagaimana ungkapan Fritjof Capra dalam Titik Balik Peradaban (1997)—membutuhkan sebuah visi yang akan memungkinkan daya dan mampu mentransmisikan dunia dalam aliran yang padu, menjadi gerakan positif bagi manifesto transformatif. Wallahu 'alam bissawab

\footnotetext{
${ }^{25}$ Lih. Hikmat Budiman, Pembunuhan Yang Selalu Gagal, Modernisme dan Krisis Rasionalitas Menurut Daniel Bell, (Yogyakarta: Pustaka Pelajar, 1997). Hal. 36

${ }^{26}$ Lih. Hassan Hanafi, Op. Cit., hal. 87 atau lih. Lessing, Tarbiyyah al-Jins al-Basyari, (Kairo: Dar al-Saqafah, 1977), hal. 72-205
} 


\section{DAFTAR PUSTAKA}

Sho'ub, Hasan. (1997). Islam dan Revolusi Pemikiran, Dialog Kreatif Ketuhanan dan Kemanusiaan, terj. Mohammad Luqman Hakiem, Surabaya: Risalah Gusti.

Assad, Muhammad. (1992). Umat Islam di Simpang Jalan, terj.

Muhammad Mahrus, Jakarta: Fikahati Aneska.

Nashir, Haedar. (1997). Agama dan Krisis Kemanusiaan

Modern, Yogyakarta: Pustaka Pelajar, cet. I.

Arkoun, Mohammed. (2001). Islam Kontemporer Menuju Dialog antar Agama, terj. Ruslani, Yogyakarta: Pustaka Pelajar, 2001.

Gautier, Guy. (1985). La Laicite en Mirror, Paris: Grasset.

Zubair, A Charis. (1997). Etika Rekayasa Menurut Konsep

Islam, Yogyakarta: Pustaka Pelajar, 1997.

Modhofir, Ali. (2001). Kamus Filsafat Barat, Yogyakarta: Pustaka Pelajar.

Furgosan, Kitty. (1995). Stephen Hawking: Pencarian Teori

Segala Hal, terj. Jakarta: Grafiti.

Hanafi, Hassan. (2003). Oposisi Pasca Tradisi, terj. Khairon Nahdiyyin, Yogyakarta: Syarikat Indonesia.

Yafie, Ali. (2003). Menggagas Fiqih Sosial, Bandung: Syarikat Indonesia.

Ali Enginer, Asghar. (2003). Islam dan Teologi Pembebasan, terj. Agung Prihantoro, Yogyakarta: Pustaka Pelajar,cet. III.

Rahardjo, M. Dawam. (2002). Ensiklopedi Al-Qur'an, Tafsir Sosial Berdasarkan Konsep-Konsep Kunci, Jakarta: Paramadina.

Husein Nasr, Sayyed. (1989). Knowledge and The Secred, New York: State University of New York.

Kuschel, Karl-Josef, et.al. (2003). Agama Sebagai Sumber Kekerasan?, terj. Imam Baehaqie, Yogyakarta: Pustaka Pelajar.

Muluk, Hamdi, 12 Mei (2003). "Split Personality" atau "Schizophrenia" Sosial? Dalam Kompas.

Shihab, Alwi. (2004). Membedah Islam di Barat, Menepis Tudingan Meluruskan Kesalahpahaman, Jakarta: PT. Gramedia Pustaka Utama.

---. (1997) Islam Inklusif, Menuju Sikap Terbuka dalam Beragama, Bandung: Mizan, cet I. selengkapnya 
pernyataan Gellner tersebut di bukunya "Flux and Reflux in The Faith of Man" dalam Muslim Society, 1992, hal. 1-85

Sunardi, St. (1993). Dialog: Cara Baru Beragama, Sumbangan Hans Kung bagi Dialog Antar Agama dalam Dialog: Kritik dan Identitas Agama, Yogyakarta: Pustaka Pelajar.

Murata, Sachiko. (1996) The Tao of Islam, terj. Rahmani Astuti dan M.S. Nasrullah, Bandung: Mizan

E. Palmer, Richard. (2003). Hermeneutika: Teori Baru Mengenai Interpretasi, terj. Mansur Hery dan D. Muhammed, Yogyakarta: Pustaka Pelajar.

Budiman, Hikmat. (1997). Pembunuhan Yang Selalu Gagal, Modernisme dan Krisis Rasionalitas Menurut Daniel Bell, Yogyakarta: Pustaka Pelajar.

Lessing, (1977). Tarbiyyah al-Jins al-Basyari, Kairo: Dar alSaqafah. 